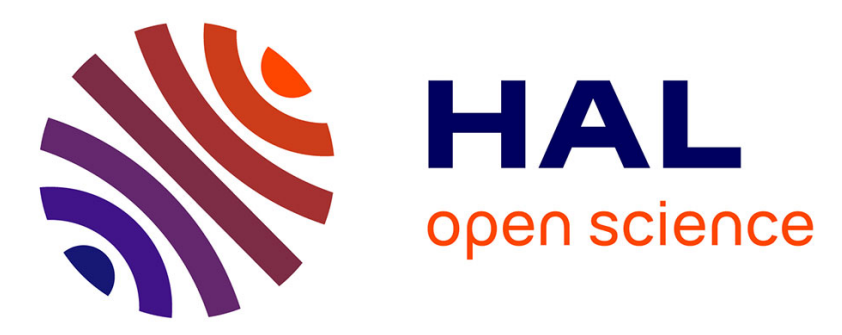

\title{
From punishment to prevention: A French case study of the introduction of co-regulation in enforcing food safety
}

Elodie Rouvière, Julie A. Caswell

\section{To cite this version:}

Elodie Rouvière, Julie A. Caswell. From punishment to prevention: A French case study of the introduction of co-regulation in enforcing food safety. Food Policy, 2012, 37 (3), pp.246-254. 10.1016/j.foodpol.2012.02.009 . hal-01323176

\section{HAL Id: hal-01323176}

https://hal-agroparistech.archives-ouvertes.fr/hal-01323176

Submitted on 30 May 2016

HAL is a multi-disciplinary open access archive for the deposit and dissemination of scientific research documents, whether they are published or not. The documents may come from teaching and research institutions in France or abroad, or from public or private research centers.
L'archive ouverte pluridisciplinaire HAL, est destinée au dépôt et à la diffusion de documents scientifiques de niveau recherche, publiés ou non, émanant des établissements d'enseignement et de recherche français ou étrangers, des laboratoires publics ou privés. 


\title{
From punishment to prevention: \\ A French case study of the introduction of co-regulation in enforcing food safety
}

\author{
Elodie Rouvière $^{1}$ \& Julie A. Caswell ${ }^{2}$
}

\begin{abstract}
In the last decade, the concept of co-regulation has been developed and increasingly promoted as an important instrument of regulation. In the context of food safety, we examine coregulation programs from the point of view of an enforcement agency. We develop a conceptual framework of enforcement of food safety regulation for use in assessing the degree of shift toward co-regulation from traditional approaches and apply it to a case study of the French import market for produce at Perpignan. We find that co-regulation in the enforcement of pesticide residue limits resulted in a change of practices for the regulatory agency from punishment to prevention based on incentives and information programs.
\end{abstract}

Key Words: Food Safety; Co-regulation; Enforcement; Import Safety

From an economic perspective, the existence of market failures is the central rationale for regulatory intervention in the provision of food safety. The market failure is due to the existence of asymmetric information about food safety attributes between producers and consumers or imperfect, symmetric information for both consumers and producers (Antle, 1996). In most developed countries, food safety regulation has focused on the imposition of standards that specify how food products should be produced and/or their final safety level.

However, since the 1990s food safety regulations have evolved worldwide and food operators have frequently been given more responsibility to monitor the safety of their products (Henson and Caswell, 1999; Loader and Hobbs, 1999; Segerson, 1999; Henson and Hooker, 2001; Codron et al, 2007). New governance structures have emerged that employ

\footnotetext{
${ }^{1}$ Corresponding author, Email: elodie.rouviere@agroparistech.fr, - AgroParisTech - GEAU, Montpellier, France.

2 Email: caswell@ resecon.umass.edu - University of Massachusetts Amherst, Dept of Resource Economics, United States of America.
} 
greater coordination between public agents and food firms. By governance structures, we mean coordination schemes (novel regulatory tools) between private and public agents that are intended to facilitate the compliance of food operators with food safety regulation. These new governance structures may be analyzed as co-regulation programs for food safety (Garcia-Martinez et al., 2007).

There is a growing literature on co-regulation but relatively little discussion has been focused on potential complementarities in the operations of regulatory agencies. In the context of the United States, Coglianese and Lazer (2003) develop a framework to analyze the conditions under which ñmanagement based regulationò will likely prove effective and explore the choices regulators confront in designing these systems. Fairman and Yapp (2005) focus on ñenforced self regulationò in the United Kingdom, particularly for small and medium-sized enterprises, investigating the impact of enforcement mechanisms on the compliance process. They show that the means of enforcement are the main drivers of compliance. Using Eijlanderôs (2005) definition of co-regulation, Garcia-Martinez et al. (2007) review all modes of co-regulation that appear in food safety regulatory processes from the standard design stage (design and implementation) to the enforcement regime (monitoring and enforcement). In their framework, enforced self-regulation systems will appear as schemes of co-regulation because in them public authorities always coordinate at a more intensive level with firms. They illustrate their analysis with case studies from North America and Europe. Garcia-Martinez et al. draw two principal conclusions: 1) the emergence of coregulation depends on the institutional environment and 2) co-regulation appears to play a greater role in enforcement regimes than in the design of regulatory processes.

None of these studies provide a comprehensive and general approach to analyze coregulation programs from an enforcement agency perspective across institutional 
environments. Here we examine the use of new co-regulation schemes focusing on a specific type of co-regulation where regulations are set and designed by public authorities and then enforced by the coordinated actions of public authorities and food operators or ñenforced selfregulationò. We look at this type of co-regulation primarily from the point of view of regulatory agencies. The first section of the paper provides a broader context for the definition of co-regulation and discusses rationales for its emergence as a means of giving more responsibility to food operators. The following section presents a conceptual model of enforcement of food safety regulations adapted from May and Burby (1998) that highlights the shifts in philosophy and approach that co-regulation may require of regulatory agencies. Based on a case study of experience in France, we find in the following section that the introduction of a co-regulation enforcement regime did induce changes in the enforcement practices of the regulatory agency. In turn, these changes in practices result in a shift from economic incentives based on punishment to incentives based on prevention. The last section provides concluding remarks and policy implications regarding modes of co-regulation for food safety.

\section{Why is co-regulation emerging?}

The concept of co-regulation was developed over the last two decades and is applied to a range of economic activities. The development mostly focuses on potential complementarities between public and private activities, and potential gains from coordination of these activities, in circumstances where there may be market failure (public goods, information asymmetries, etc.). Researchers have explored these potential complementarities and gains from coordination in many different institutional environments and areas of regulation including environmental protection (Gunningham and Grabosky, 
1998), e-commerce (Goldsmith and Wu, 2006), media (Dordeck-Jung et al., 2010), and food safety (Garcia Martinez et al, 2007).

The introduction of these new regulatory tools has also launched a wide discussion among scholars. For instance, Black (2001) provides a core debate on the emergence of this new type of regulation arguing that it has changed the whole understanding of regulation per se. She discusses self regulation as a solution to the limits of command and control and highlights the importance of managing this novel regulatory tool as it becomes more broadly used.

However, the definition of co-regulation often lacks clarity and varies among scholars, regulatory agencies, and institutions. Eijlander (2005) defines co-regulation as an approach in which a mixture of instruments is brought to bear on a specific problem. Co-regulation therefore emphasizes coordination between public and private agents in the regulatory process (Eijlander, 2005). This coordination in the field of regulation may result in various forms of governance, such as agreements, conventions, and even regular laws. For Gunningham and Rees (1997), regulation can be perceived as consisting of a continuum ranging from detailed command and control regulation to pure self-regulation (no intervention) that can involve coregulation. Sinclair (1997) also suggests there is a rich range of policy options somewhere along the spectrum between these ends. According to the Organisation for Economic Cooperation and Development (OECD) (2002), the regulatory role is shared between government and industry under co-regulation. Ayres and Braithwaite (1992) define coregulation as industry self-regulation that government oversees and/or ratifies. As noted above, Coglianese and Lazer (2003) and Fairman and Yapp (2005) respectively refer to ñmanagement-based regulationò or ñenforced self-regulationò. 
The food safety literature has widely addressed the issue of complementarities between food operators and public regulation in better providing and monitoring food safety. These complementarities increasingly have been promoted through changes in food safety regulations giving food operators more responsibility for food safety. Scholars have focused on the private incentive aspects of complying with food safety regulation. Food operators balance the costs and benefits of implementing procedures to comply with food safety regulations, choosing from a continuum that ranges from full compliance to non-compliance (Henson and Heasman, 1998). They also assess their costs and benefits relative to internal (resources) and external (reputation, penalties) incentives. They adopt safety measures according to their budget constraints, their strategies, and the structure of the market (Loader and Hobbs, 1999).

As noted, there is a consensus that co-regulation lies somewhere in the middle between command and control intervention and no intervention (see, e.g., Garcia-Martinez et al., 2007, Sinclair, 1997 and Black, 2001). Command and control intervention results in regulatory requirements for firms that are administered and enforced by public authorities. No intervention refers to situations where there are no specific regulatory requirements for firms. In such a case, pure self-regulation may emerge. In these schemes, rules are set, administered, and enforced by firms on themselves (Nunez, 2007). It is often implemented through private incentives to industry (Bartle and Vass, 2005). Some scholars who deal with food safety and quality consider pure self-regulation schemes in food safety or quality as private standards (e.g. Garcia-Martinez and Poole, 2004; Henson and Reardon, 2005; Fulponi, 2006). However, the distinction between self-regulation and co-regulation lacks clarity. According to Bartle and Vass (2005), the main criterion of co-regulation is the cooperation between public authorities and firms in the regulatory process. Sinclair (1997) proposes regulatory variables 
that can be used to better match regulatory options with particular regulatory issues. For instance, Gunningham and Sinclair (2005) consider different policy options to provide the ideal regulatory outcome for agricultural non-source pollution.

Co-regulation may arise in the process of creating new legislation or regulatory rules by incorporating the opinions of companies, consumers, voters, non-governmental organizations, and other stakeholders. The purpose of enforcement in food safety regulation is to monitor and enforce compliance from companies; it is the responsibility of regulatory agencies. According to Bartle and Vass (2005), co-regulation in enforcement involves all modes of regulation in which regulations are designed and set by public authorities and enforced by the coordinated actions of public authorities and regulated firms. An example is a voluntary agreement that takes the form of a common set of good practices supported by the government that promotes company compliance with regulatory requirements. According to this definition, ñenforced self-regulationò (Ayres and Braithwaite, 1992; Coglianese and Lazer, 2003; Fairman and Yapp, 2005) appears similar to this concept of co-regulation.

Henson and Caswell (1999) distinguish between three types of standards according to the level of flexibility they offer to food operators. Imposing a general target standard puts fewer constrains on the behaviour of food operators. Public authorities do not define a specific safety level for the product or the process. The pressure from public authorities comes from liability the firm may experience when there is a product defect that causes damages to consumer health. With performance standards (e.g., pathogen counts for products at some stage of the supply chain), public authorities require food operators to achieve prescribed product quality standards but the means to reach the standard are not specified by the authorities. Specification standards are the most stringent. Under them public authorities 
define how food operators must produce the product. Food operators who fail to reach the standards commit offenses that usually result in sanctions.

The emergence of co-regulation in enforcement generally corresponds to a shift from specification to performance standards and may involve an increased or reduced reliance on target standards (liability). Lee and Marsden (2009) describe the roots of the co-regulation dynamic in food safety regulation in the United Kingdom. They argue that the Food Safety Act in 1990, which placed more responsibility of private parties, was the first step in the development of co-regulation in food supply chains where private interests and contracting in global markets take a prominent place. As a consequence, private regulation of food quality and food safety has been stimulated through the emergence of private standards owned by retailers. These and subsequent developments have modified the whole organisation and governance of the supply chain in providing and monitoring food safety (Fulponi, 2006).

In the United States, prior to 1996 most food regulation required food operators to implement specification standards. This began to change with the adoption of mandatory Pathogen Reduction-Hazard Analysis Critical Control Points (PR-HACCP) for the meat and poultry industries (Loader and Hobbs, 1999). In connection with the new regulation, the Food Safety and Inspection Service developed a series of guidebooks on how to implement PRHACCP to assist firms in complying. HACCP was then implemented by the U.S. Food and Drug Administration for the seafood industry in 1999 and for some juices in 2001. Similar developments have occurred in Europe. In 2001, European Regulation (EC) No 178/2002, also called the ñFood Law,ò was issued. It is characterised by the increased involvement and responsibility of private actors with regard to food safety controls. For example, since 2001 importers of fresh produce have been responsible for safety controls within their firms and therefore must implement a system of self-monitoring aimed at checking whether imported 
products satisfy the Maximum Residue Limits (MRLs) for pesticides defined by European law (Rouvière et al., 2010).

The emergence of co-regulation as a novel regulatory tool to enhance compliance from food operators in enforcement of food safety regulations is widely acknowledged. For example, the U.S. Food and Drug Administrationô Food Protection Plan (2007) calls for promotion of increased corporate responsibility to prevent foodborne illness. From a policy perspective, it is important to understand the forms that co-regulation is taking in enforcement and to analyze its impacts.

\section{A framework for analyzing co-regulation in regulatory enforcement regimes}

The literature on enforcement has widely addressed enforcement regimes taking regulatory agencies as the unit of analysis. As noted above, co-regulation can take many forms when incorporated into enforcement regimes. Co-regulation can be all the possible combinations between public and private mechanisms leading to a novel regulatory tool which can be implemented to help food operators to become compliant with regulations. For instance, as suggested by Fairman and Yapp (2005), free education and advice approaches might be used by regulatory agencies to increase compliance. We hypothesize that adoption of a coregulation approach leads to systematic changes in enforcement regimes.

Regulation may be ex-ante in the form of regulatory standards and enforcement or ex post in the form of liability. We focus on ex-ante regulation. Figure 1 presents an analytical framework for mapping and assessing changes in ex-ante enforcement regimes adapted from May and Burby (1998). May and Burby (1998) divide the enforcement regime for ex ante regulation into three parts. 
- Enforcement philosophy: the role an agency plays in inducing companies to comply with regulatory requirements. May and Burby (1998) distinguish between reactive and proactive approaches. The two differ in their purpose and how public authorities react when they detect that a regulatory offence has occurred. A reactive approach seeks to identify food operators that do not comply with regulations and penalize them with sanctions. A proactive approach seeks to implement measures that are necessary to avoid a breach of the regulation, including, for example, education and coaching. It is a preventive approach to inducing compliance from firms.

- $\quad$ Enforcement strategy: how the agency combines its practices in order to induce company compliance. Enforcement strategies are classified into two broad categories. Strict enforcement relies on strict application of rules, with inspections carried out in order to punish major regulatory offences. Creative strategies promote compliance through, for example, the use of market incentives or relaxed inspections.

- Enforcement practices: the different sets of practices available to regulatory agencies to enforce regulations. These are discussed in detail below.

As shown in Figure 1, the framework puts analysis of enforcement practices at the center. Again following May and Burby, we use analysis of the observed enforcement practices implemented by a regulatory agency to draw conclusions about the underlying enforcement philosophy and strategy. The major classes of enforcement practices analyzed are inspections, information, and sanctions.

Inspections: There are two types of inspections that a public agency can implement for enforcement of food safety regulations. First, official inspections can be performed by 
regulatory agencies through formal and random or scheduled on-site visits. The focus of these inspections may be product or process-oriented. Product-oriented inspections focus on the safety level of the product (e.g., pathogen counts for products at different stages of the supply chain, the level of pesticide residues in produce) and occur before or after the release of the product on the market. Process-oriented inspections focus on the procedures that food operators have implemented to prevent food safety failure. Inspections are intended to deter food operators from failing to perform the appropriate procedures.

Second, official inspections may be carried out through self-reporting or registration. Self-reporting allows for second level inspections where regulatory agencies evaluate a firmôs compliance by monitoring its records. Based on individual records, enforcement agencies can assess a firmố internal rules (testing, corrective procedures, and actions taken) and check whether firms have implemented their quality/safety management system correctly. Under registration, regulatory agencies implement third level inspections where they assess food operatorsô compliance through formal verifications made by third party accreditors. Enforcement agencies may support such third party accreditation bodies by issuing quality labels or signals for firms that have achieved a certain standard (e.g., organic production).

Information: The source of a firmôs non-compliance often is a lack of knowledge and understanding of regulation principles and compliance processes (Fearne et al., 2005). Reliable information and education/training programs may be a good means to achieve high rates of compliance (Fearne et al., 2004) by promoting the potential gains in business performance from compliance (Fearne et al., 2005). Technical support programs are designed to help food operators find and implement effective ways to achieve the required food safety level at least cost. Information programs take multiple forms that may be used separately or in 
combination: diffusion of up-dated regulations, coaching and training programs, and education programs.

Regulatory agencies can also use information disclosure to consumers or others along the supply chain as a market mechanism to encourage the adoption of compliant practices by food operators. For example, awards and labels can be used as positive market signals. These market signals are also useful in reducing information asymmetry between parties and facilitating customer decision-making when faced with the credence attributes of food products. Depending on consumer awareness, market mechanisms based on information could provide significant incentives to food operators that wish to preserve or build their market shares and reputation.

Sanctions: We distinguish between three types of sanctions. All are generally used in connection with inspection practices.

Repressive sanctions: Regulatory agencies can use penalties, prosecution, and recalls to punish intransigent food operators for committing an offence or repeatedly breaching regulations. Sanctions for non-compliance may include the closure of facilities, seizure of products, and disqualification from the market.

Informative sanctions: Following a breach in regulations, enforcement agencies may mandate certain corrective actions in order to motivate food operators to comply. There may be a hierarchical spectrum of sanctions depending on the severity of the regulatory offence. Less severe violations may result in advice, notices, and warnings being given to encourage non-compliant firms to reach compliance through corrective actions. These corrective actions can be imposed by the authorities and/or left to the discretion of food operators.

Sanctions through negative information provided to consumers: Regulatory agencies can display the results of official inspections and findings in order to disclose information 
about food operators to their customers. These are often referred to as ñnaming and shamingò programs. The names of non-diligent companies are posted on the Internet, in newspapers, or at places of business. Another example is obliging food operators to display inspection results to keep customers informed. This is the purpose of the ñscores on doors programsò that the United Kingdom Food Safety Agency has been implementing for food service establishments since 2006.

As noted above, the combination of enforcement practices implemented by a regulatory agency can be used to analyze both the enforcement philosophy and strategy. As shown in Figure 1, we characterize a traditional enforcement scheme as one that uses inspections and repressive or negative information sanctions as the predominant enforcement practices. This is indicative of a reactive enforcement philosophy and a strict enforcement strategy. We characterize a co-regulation scheme as one that uses information approaches and informative sanctions predominantly. This indicates a proactive enforcement philosophy and a creative enforcement strategy. From a policy perspective, the degree of shift in an enforcement regime towards co-regulation can be evaluated by comparing the suite of enforcement practices used before and after the change. This evaluation using the framework presented in Figure 1 allows an understanding of the actual design versus the rhetorical representation of enforcement regimes and serves as a foundation for assessing the impacts of enforcement changes.

\section{From punishment to prevention in enforcement: A case study of the French import market for fresh produce}

We apply the framework through a case study of changes in the enforcement regime in the French import industry for fresh produce that were adopted beginning in 2001. Our 
purpose is to map and assess changes in the enforcement regime after implementation of this co-regulation scheme. These changes have been characterized as a shift from a traditional to a co-regulation approach. From our perspective, the degree of this shift can be evaluated through an analysis of changes in enforcement practices that indicate the actual shift in enforcement strategy and philosophy. The case study is of one of the three main French import markets for fresh produce located in Perpignan in the south of France ${ }^{3}$. It explores how co-regulation has emerged in enforcement in this import market following the issuance of European Regulation (EC) No 178/2002. This regulation imposed greater responsibility on food operators for monitoring and providing food safety.

We use data and information from two surveys conducted in 2006. The first survey is qualitative and was conducted with public authorities in charge of food safety controls. The second survey was of importers operating in the Perpignan market. Of the 98 importers surveyed, 66 firms participated in the co-regulation program we analyze. Respondents were asked questions during a face-to-face, one hour interview about the firmôs situation in 2005 such as total sales, main product imported, and number of pesticide analyses conducted, as well as about their procurement practices, suppliers, and customers. For firms participating in the co-regulation program our questionnaire also included some qualitative questions about the firm's perception of changes with it.

\subsection{The co-regulation program in the French import industry for fresh produce}

The major parties in the French import industry are the importers, the Board of Importers, and the public authorities. In 2001, importers from the Perpignan import market

\footnotetext{
3 There are three import markets in France: Perpignan, Rungis, and Marseille. In 2004, France imported 2.7 million tons of produce. The Perpignan market accounts for 50.8\% of this volume, followed by Rungis (34.4\%) and Marseille (14.8\%). The market in Marseille does not have a co-regulation enforcement program in effect. There is a program in the Rungis market but it is not linked to the one in Perpignan.
} 
negotiated with public authorities to introduce a voluntary safety program carrying out laboratory analyses to monitor the amounts of pesticide residues in fresh produce imported into the European Union. This program proposed by the importers was then negotiated with and approved by the General Service for Consumption, Competition, and the Repression of Fraud (DGCCRF), one of the public authorities in charge of enforcing the law and monitoring food safety in France. The role of the DGCCRF in the program is to evaluate whether the safety process proposed by the firms is effective. Negotiations have been mostly around defining the safety effort that importers would provide and also on the magnitude of the oversight provided by DGCCRF, which is its main function in the program. While the coregulation program was initiated by private agents, the DGCCRF has benefited from its existence through being able to reallocate scarce public resources for monitoring food safety to industries where this kind of scheme does not exist. Moreover, public authorities argue that this private initiative increases the number of controls conducted on imported products, creating more legitimacy for importers in comparison to French producers.

This voluntary safety program fits the definition of co-regulation in enforcement developed in the above sections. Both public and private agents (importers) claim that the first motivation in implementing this program was to achieve better levels of safety for fresh produce entering the French and European market (Codron et al., 2007).

In France and Europe, the safety evaluation for the fresh fruit and vegetables sector relies on Maximum Residue Limits for pesticides (MRLs) set by the European authorities (Regulation (EC) No 396/2005) or French regulation (Decree 04/08/1992, as amended). According to these laws, residues found in or on produce are judged as being above, at, or below the limit. Thus the safety of fresh produce in France is one-dimensional, as opposed to 
the United States, for example, where regulation of the safety of fresh produce also refers to the presence of microbiological hazards such as E. coli and Salmonella.

For the importer, the primary way to monitor the safety of fresh produce is to carry out multi-residue laboratory analyses. A single multi-residue analysis costs about $\mathrm{u}^{3} 00^{4}$ and there are no economies of scale in performing analyses. Under the regulatory system, French importers must comply with a pesticide residue performance standard; they must achieve the prescribed product quality standards and/or safety level. The means to achieve the safety standard are left to their discretion (Henson and Caswell, 1999). Under French law, the party or parties in control of pesticide use during the production and post-harvest periods are considered to be producers. Importers are thus producers and face a strict liability rule if they do not comply with the performance standard.

The co-regulation program, called the ñDémarche Qualitéò, agreed upon by the government and importers in the Perpignan market is comprised of two contract agreements. The first is between the importers and the Board of Importers, while a second links the Board to public authorities. The importers are thus not committed to the public authorities directly but instead are responsible to their Board. The Board is in turn responsible to the public authorities.

For importers, the co-regulation program is a code of conduct for controlling the safety level of supplies. It defines procedures that are based on the principles of the Hazard Analysis Critical Control Points (HACCP) method. The costs involved in joining the program are twofold. First, importers must pay an annual subscription fee of ú1,000. Second, they must allocate human and financial resources to monitoring. Importers who join the co-regulation

\footnotetext{
${ }^{4}$ Importers who are part of the program benefit from a discount for analysis, with the cost reduced to ú160.
} 
program must arrange an individual laboratory analysis for each úl million of sales. They also must assign an employee to manage quality control.

\subsection{Operation of the co-regulation program in the Perpignan market}

During the summer of 2006, we conducted a survey of firms that participate in the Perpignan produce import market. Of the 98 firms that were operating in this market, 66 $(67 \%)$ were members of the co-regulation program, while $32(33 \%)$ were not (see Table 1$)$. Most of participating firms $(61.5 \%)$ joined the program when it was introduced in 2001 . In 2008, the number of participating firms was the same as in 2005, indicating a stable agreement. Table 1 shows that all of the importers participating in the co-regulation program responded to the survey, while just over one-third (12 of 32) of the non-participating importers responded.

The average turnover ${ }^{5}$ of the participating firms in 2005 was úl6.6 million, with a standard deviation of about $100 \%$. About $50 \%$ of the firms are small and medium firms with less than ú10 million in sales in 2005; compliance may be an issue for these firms. Fearne et al. (2005) establish that co-regulation schemes can be particularly important in helping small and medium sized firms to comply with emerging regulations. The two main products imported by participating firms are tomatoes (for 19.4\% of firms) and citrus (e.g., oranges, limes) fruits (for $19.4 \%$ of firms). The leading countries of origin for the main products imported in France are Spain (64.5\% of volume on average) and Morocco (18\%). Citrus fruits

\footnotetext{
${ }^{5}$ Because of missing values, all descriptive statistics are given for a stable sample composed of 62 firms.
} 
and tomatoes have been on specific watch plans set by the DGCCRF and the European Union that include the 10 riskiest fruits and vegetables with regard to pesticide residues. ${ }^{6}$

Participation in the co-regulation program requires multi-residue testing and the employment of a quality manager. Most of the firms (66\%) who participated in the program did not employ a full-time quality manager. One of the employees (most often the forklift operator) is assigned to this function. At the beginning of every year, the quality manager sets out a sampling plan for products that are more likely to show excess pesticide residues based on the types of produce being imported. Table 2 shows that $19.4 \%$ of program participants based their sampling plans on the products that public authorities had defined as risky (see footnote 4$), 58.1 \%$ on the highest volume products, and $22.5 \%$ on all products. Our survey suggests that importers who are not part of the co-regulation program do not conduct laboratory analyses. None of the 12 firms that participated in the survey but did not participate in the program conducted laboratory analyses.

Importers in the program conducted an average 24.5 analyses a year in 2004 and 26.8 in 2005 . In $2005,75 \%$ of the firms conducted less than 30 analyses. In comparison, only $50 \%$ of the participating importers said that they had ordered laboratory analyses to detect levels of pesticide residues before implementation of the program. Their recall of their behavior is consistent with the perception of it expressed in interviews by the public authorities in charge of control. In addition to more residue testing by firms in the co-regulation program, the firms also had to appoint a quality manager and implement a sampling plan. Together these changes constitute a new routine in regard to the safety of supplies.

\footnotetext{
${ }^{6}$ The 10 riskiest products for pesticide residues as identified by the DGCCRF and the European Union are citrus fruits, celery, grapefruit, strawberries, sweet melons, sweet peppers, potatoes, lettuce, tomatoes, and peaches.
} 
While the absolute number of analyses gives one indication of firmsôinvolvement in the program, the number of analyses per unit of sales (in million ú) provides a measure of the intensity of the safety effort and compliance within the program (Rouvière et al., 2010). Measuring firmsôsafety effort as the ratio of the number of analyses per úl million in sales allows us to control for the effect of size on the absolute number of analyses. For example, consider that Firm A is twice as large as Firm B and that they both conduct 10 analyses a year. The absolute effort is the same for both firms whereas the intensity of effort by Firm B is twice as high as for Firm A. Figure 2 shows the distribution of the safety effort by firm size in the sample of participating firms. It shows that effort is decreasing with firm size. Moreover some firms (15 out of 62) did not comply with the programôs requirement of one analysis per úl million of sales (i.e., safety effort is less than 1). This suggests that the minimum requirement is not strictly enforced by the Board of Importers. At the time of the survey, the public authorities did not consider this behavior as noncompliance by firms. In contrast, the other 47 firms made an effort equal to (1 firm) or above (46 firms) one analysis per úl million of sales indicating that some firms had incentives to go beyond the minimum requirement.

Importers are required to report to the public authorities the results of analyses that show levels of pesticides above the legal MRLs. Table 3 shows the number of failures reported by importers during 2005. There were no failures for 17 firms (27.4\%), while 23 firms $(37.1 \%)$ reported only one safety failure and 11 companies $(17.7 \%)$ reported two. One importer $(1.6 \%)$ detected 8 failures in 2005. This situation is quite rare but can occur particularly when products are on the top 10 riskiest products list for pesticide residues (see footnote 4). 
The central position of the Board of Importers gives it the status of guarantor of the importersô commitment to the program. This is an administrative organisation; the Board members are not involved in the import sector. They are paid by the importers and assume an administrative role representing them. The Board is the ñspokespersonò for the importers. It negotiated the agreement with the public authorities on behalf of the importers.

Under the implementation of the co-regulation program, the Board is the dedicated contact for the public authorities. It must ensure the controls used by the importers, for example that they follow their sampling plans. The Board gathers information on the number of analyses conducted by the firms participating in the program. However, this is not made publicly available to customers (retailers or wholesalers) or to the public authorities who are not allowed to have any information on an individual importerôs safety effort. However, when there is a safety failure, the Board must warn the DGCCRF about the origin of the failure (the name of the company) and communicate the results of the analysis. Every year, the Board submits a report to the French authority, the DGCCRF, which summarizes all the preventive actions importers have implemented during the year. The report provides information such as the total number of analyses done by importers, the number of pesticide analyses conducted on risky products (see footnote 4), and the total costs of the program. In 2008, the Board reported more than 1600 pesticide analyses, which was more than the about 1300 it had expected, with $78 \%$ of those analyses being done on risky products. The nonconformity rate was about $4.4 \%$, which is comparable to the nonconformity rate for fresh produce at the national level during inspections conducted by the agents of the DGCCRF. In 2008, the total cost of the co-regulation program supported by importers was ú209,805 (before taxes), which represents an average cost of analysis by firms of úB,278. 
Public authorities use this annual report to support their involvement in the program. They can dismiss the agreement if they assess that importers and their Board do not satisfactorily comply with their individual commitments. In 2009, the public authorities legally renewed the recognition of the program, which suggests that they were satisfied with the outcomes. This action reinforces the considerable changes in enforcement practices, as discussed below, made in negotiating the agreement.

\subsection{Changes in regulatory agency enforcement practices}

We analyze the degree of shift in the regulatory enforcement regime from traditional to co-regulation in the Perpignan market using the framework presented in Figure 1 . The framework begins with an analysis of regulatory practices and then draws conclusions about enforcement strategy and philosophy. The regulatory agency (DGCCRF) normally performs official inspections in order to detect non-compliant firms. Agents mostly conduct regular onsite, product-oriented inspections at the import point or at the retail level. In the case of fresh produce, samples are collected and laboratory analyses are carried out to check that residue levels are within the legal limits. In an official inspection, inspectors randomly select a box of fruit or vegetables (e.g., a box of tomatoes or apples), take one or two pieces of the produce as a sample of the box, and send the samples to the official laboratory, which conducts multiresidue analyses. Once an official laboratory confirms a case of non-compliance, importers are found guilty of an offence. Sanctions are repressive and range from a warning letter to prosecution and fines. At the same time, the whole box of the incriminated produce is taken off the market. The 32 firms in the Perpignan market that do not belong to the voluntary program thus operate under a traditional enforcement regime characterized by a strict 
enforcement strategy and reactive enforcement philosophy. They face a strict liability rule in a case of safety defect.

The introduction of the co-regulation program changed the entire organization of official safety controls for the importers participating in the program. For these importers, there is a gap between the letter of the law and its enforcement. The changes affected all areas of enforcement practices: inspections, information, and sanctions.

Inspections: The survey we conducted with importers during the summer of 2006 contained several qualitative questions. For instance, we asked participating firms how they would characterize changes in the regulatory agencyôs enforcement practices. Of the 62 companies in our sample, $28(45.2 \%)$ said that the number of inspections was lower since they joined the program than when it was not in place. From our qualitative survey with public authorities we found that the routine of the regulatory agency in performing official inspections did change. Official inspections have become second-level controls, with authorities relying on the record-keeping and self-monitoring provided by the importers. Also, under the co-regulation program, importers self-report safety failures, with official inspectors assuming that importers are operating in good faith. Officials interviewed highlighted that as a result of the program they can reallocate resources to monitor riskier food operators. In other words, the reduction of inspections in the co-regulation program allows them to better monitor and inspect the practices of others food operators.

When a failure is detected (at the import point or at the retail level) by the regulatory agency, inspectors come to assess the importersô safety procedures. When the safety procedures are deemed to be correct, the importer is not held liable for the failure. For importers this is the most important commitment of the public authorities in the program: participation in the program allows importers to be found liable (under a strict liability rule) if 
and only if they have failed to take due care (defined as conducting no analyses). In the event of a safety failure (at the import or retail point), an importer will be considered as having acted in good faith and the public authorities will apply a negligence based rule rather than the strict liability rule that is applied to nonmembers.

Information: Importers are expected to know and comply with the law; ignorance of the law is no excuse. In the co-regulation program, importers benefit from an information scheme providing regular updates on regulations furnished by the regulatory agency. The objective is to keep importers informed concerning regulations in their industry, both at the European and French level. Regulatory information is centralized by the Board of Importers and is then diffused free of charge to participating importers. Moreover, meetings are organized by the Board to discuss the introduction of major developments in regulation that have a significant impact on how business is conducted. For instance, the introduction of the European Food Law (Regulation EEC 178/2002) and mandatory traceability was fully discussed in terms of the consequences for importers. Nonmembers have to keep informed of evolving regulations by their own means.

In addition to regular regulation updates, the agreement provides a mandatory training program for the firmsôquality managers. It is organized each year by the regulatory agency. People in charge of quality must take classes on quality, methods, and risk management in order to implement the agreementôs procedures in the most appropriate way. In 2008, 103 people took this training program indicating that on average more than one person is assigned to quality functions in participating firms. Moreover, as an information practice the regulatory agency promotes the agreement by allowing participating firms to use a special logo on their bills of sales. The logo allows firms to differentiate themselves from their rivals and indicates the official support of the authorities for the agreement. Importers can thereby signal that their 
produce is safer or more closely checked and indicate their commitment to safety to their customers. However, this logo remains a business-to-business signal and cannot be used as a consumer label. $^{7}$ In 2005 , most of the interviewees said that at that time the program was difficult to promote with customers and they were not getting any price premium for selling more closely monitored products.

Sanctions: The negligence liability provided by the co-regulation program resulted in sanctions and prosecutions for failures being very rare for participating firms. As reported by them, none of 66 participating firms has been prosecuted following an action by the DGCCRF for safety defects since their involvement in the program. The Board validated this claim that the global number of prosecutions has been drastically reduced to zero since 2001 .

\subsection{From punishment to prevention: Changes in enforcement strategy and philosophy}

Our case study of the adoption of the ñDémarche Qualitéò program for imported produce in the Perpignan market indicates that there was a systematic shift in enforcement practices for participating firms to a co-regulation approach as characterized in Figure 1. Nonparticipating firms remained under the traditional strict enforcement regime. The new approach is characterized by a creative enforcement strategy and a proactive enforcement philosophy that is more oriented toward compliance. For participating companies, the enforcement of safety regulation now focuses more on prevention rather than on punishment and deterrence. The enforcement approach is preventive because it intervenes prior to the occurrence of safety offences (through training and education programs) and provides

\footnotetext{
7 Under French law, the safety attributes of fruit and vegetables are difficult to promote to consumers. Firms must be able prove their claims concerning the attributes of a product. In the event of false or unfounded claims, they are liable under crime law (Codron et al., 2007).
} 
incentives (the use of a logo, relaxed inspections) to firms that participate in the program. The role of the regulatory agency has shifted toward co-regulation by providing assistance, incentives, and support to food operators for respecting regulations.

In the case studied, the implementation of a more proactive approach in the enforcement of food safety regulations appears to be sustainable for two reasons. On the one hand, the regulatory agency designed and implemented effective incentives. For example, the use of market mechanisms (such as a logo or label) works as a positive incentive to participate in the program. Buyer-oriented information disclosure indirectly induces food operator compliance with the regulatory requirements. On the other hand, agencies provide technical support, education, and training programs to help firms become compliant. The combination of incentives and prevention constitutes a proactive approach.

The new method of enforcing food safety regulation implies the use of new routines by official inspectors to suit the proactive approach. They must become familiar with and use new tools of monitoring (self-reporting). They must also provide technical assistance and supervise education and training programs. The capacity of official inspectors to adapt is an important feature of the introduction of co-regulation in the enforcement regime. The shift from punishment to prevention and facilitation requires a fundamental change in culture on the part of enforcement officials. As Yapp and Fairman (2006) point out, they must learn to act as educators rather than policemen.

In this case study, we observe that the whole organization of safety controls in the Perpignan import market has been modified for public and private agents that are part of the co-regulation program. Co-regulation has modified their behavior through more coordinated actions to reach a common goal of better checking produce entering the French and thus the European market. With available data we are unable to assess if the introduction of co- 
regulation has improved the level of safety of imported produce in France. However, we can make a first step in assessing the impacts of enforcement changes.

Under co-regulation, public agents have become and have to act as educators helping firms to comply with the regulation and providing training. There is less focus on sanctions and more on understanding why firms do not comply with safety standards. The companies have in turn introduced a really new process into their operating environment. Monitoring safety on a regular basis has become a central focus, although levels of safety effort vary considerably. The firms are now aware of the importance on their involvement in doing analyses and of their role as gatekeepers with regard to food safety.

These changes resulted in a modification of the relationships between inspectors and importers that is more balanced. Public and private parties share the same goal of improving the safety of imported produce whereas their individual objectives might differ. The relationship has moved toward a partnership in monitoring the safety of produce. Importers have changed their image of the agency looking more to win-win engagement with it. Both agents contribute to the provision of food safety, which rather than being a sole public policy issue also depends on the management of the private supply chain.

The next step in evaluating co-regulation is to assess its effect on safety. For instance, one means of doing so is to evaluate the evolution since the introduction of the program of the rate of compliance by participating and non participating firms. Another means is to track the safety effort of firms and asses the quality management systems they have implemented. Both approaches would require detailed data at the firm level.

\section{Concluding remarks}


We contribute to the current debate on the use of co-regulation in the enforcement of food safety regulations. This co-regulation mainly refers to a shift in regulatory practices in the areas of inspections, information, and sanctions. Co-regulation has increasingly been promoted as a means of transferring more responsibility to food operators. We provide a framework for assessing the degree of movement in regulatory practices, strategy, and philosophy toward co-regulation. We apply this model to assess the degree of movement toward co-regulation with the adoption of the ñDémarche Qualitéò program for imported produce in the Perpignan market in France. We conclude that in this case enforcement practices moved from a punishment to a prevention mode by providing incentives and information. Further research is needed to evaluate how the modifications under the coregulation program affected the level of food safety in the market.

From a policy perspective, the promise of co-regulation approaches is that they may be more effective than traditional alternatives in reaching compliance goals and desired levels of food safety. In order to do so, co-regulation programs must provide the correct incentives and enough support to reach these goals. Further research should consider the design of programs in terms of incentives for food operators and designs for monitoring by public authorities. Moreover, research must be undertaken to assess the performance of co-regulation schemes in terms of rates and levels of compliance, actual delivered food safety, and costeffectiveness compared to traditional regulatory approaches. 


\section{REFERENCES}

Antle, J.M., 1996. Efficient food safety regulation in the food manufacturing sector. American Journal of Agricultural Economics. 78, 242111247.

Ayres, I., Braithwaite, J., 1992. Responsive Regulation, Transcending the Deregulation Debate. New York: Oxford University Press.

Bartle, I., Vass, P., 2005. Self-regulation and the regulatory state: A survey of policy and practices. Research Report, University of Bath: 76p.

Black, J., 2001. Decentring Regulation: Understanding the Role of Regulation and Self Regulation in a 'Post-Regulatory' World. Current Legal Problems. 54, 103-147.

Coglianese, C., Lazer, D., 2003. Management-based regulation: prescribing private management to achieve public goals. Law \& Society Review. 37, 691ї 730.

Codron, J-M., Fares, M., Rouvière, E., 2007. From public to private safety regulation? The case of negotiated agreements in the French fresh produce import industry. International Journal of Agricultural Resources, Governance and Ecology. 6, 415-427.

Dordeck-Jung, B., Oude Vrielink, M., Gosselt. J., van Hoof, J., de Jong, M., 2010. Contested hybridization of regulation: Failure of the Dutch regulatory system to protect minors from harmful media. Regulation \& Governance. 4, 154-174.

Eijlander, P., 2005. Possibilities And Constraints In The Use Of Self-Regulation And CoRegulation In Legislative Policy: Experience In The Netherlands ï Lessons To Be Learned For The EU? Electronic Journal of Comparative Law. 9(1). 
Fairman, R., Yapp, C., 2005. Enforced Self-Regulation, Prescription, and Conceptions of Compliance within Small Businesses: The Impact of Enforcement. Law \& Policy. 27 (4), 491-519.

Fearne, A., Garcia-Martinez, M., Bourlakis, M., Brenan, M., Caswell, J., Hooker, N., Henson, S., 2004. Review of the Economics of Food Safety and Food Standards, Document prepared for the Food Safety Agency, Imperial College London, London: 83p.

Fearne, A., Garcia-Martinez, M., Caswell, J., Henson, S., Kharti, Y., 2005. Exploring Alternatives Approaches to Traditional Modes of Regulation of Food Safety, Imperial College London, London. Document prepared for the Food Safety Agency: 127p.

Fulponi, L., 2006. Private Voluntary Standards in the Food System: The Perspective of Major Food Retailers in OECD Countries. Food Policy. 30 (2), 115-128.

Garcia-Martinez, M., Poole, N., 2004. The Development of Private Fresh Produce Safety Standards: Implications for Developing Mediterranean Exporting Countries. Food Policy. 29(3), $29 і ̈ 255$.

Garcia-Martinez, M., Fearne, A., Caswell, J., Henson, S., 2007. Co-regulation as a possible model for food safety governance: Opportunities for publicï private partnerships. Food Policy. 32(3), 299-314.

Goldsmith, JL., Wu, T., 2006. Who controls the Internet? New York: Oxford University Press, 226p.

Gunningham, N., Grabosky, P., 1998. Smart Regulation: Designing Environmental Policy. Oxford: Clarendon Press: 494p. 
Gunningham, N., Rees, J., 1997. Industry Self Regulation, An institutional Perspective. Law and Policy. 19(4), 363-414.

Gunningham, N., Sinclair, D., 2005. Policy instrument choice and diffuse source pollution. Journal of Environmental Law. 17(1), 51-81.

Henson, S., Caswell, J., 1999. Food Safety Regulation: An Overview of Contemporary Issues. Food Policy. 24(6), 589ї 603.

Henson, S., Heasman, M., 1998. Food Safety Regulation and the Firm: Understanding the Compliance Process. Food Policy 23, 9-23.

Henson, S., Hooker, N., 2001. Private Sector Management of Food Safety: Public Regulation and the Role of Private Controls. International Food and Agribusiness Management Review. 4, 7-17.

Henson, S., Reardon, T., 2005. Private agro-food standards: Implication for food policy and the agro-food system. Food Policy. 30(3), 241-253.

Lee, R., Marsden, T., 2009. The Globalization and Re-localization of Material Flows: Four Phases of Food Regulation. Journal of Law and Society, 36(1), 129-44

Loader, R., Hobbs, J., 1999. Strategic Responses to Food Safety Legislation. Food Policy 24(6), 685-706.

May, P., Burby, R., 1998. Making Sense Out of Regulatory Enforcement. Law and Policy. 20(2), 157-182.

Nunez, J., 2007. Can Self-Regulation Work? A Story of Corruption, Impunity and Cover-Up. Journal of Regulatory Economics. 31, 209-233. 
Organisation for Economic Cooperation and Development (OECD). 2002. Regulatory Policies in OECD Countries, From Interventionism to Regulatory Governance. Report OECD: 10p.

Rouvière, E., Soubeyran, R., Bignebat, C., 2010. Heterogeneous Effort in Voluntary Programmes on Food Safety: Theory and Evidence from the French Import Industry of Fresh Produce. European Review of Agricultural Economics. 37(4), 479-499.

Segerson, K., 1999. Mandatory versus Voluntary Approaches to Food Safety. Agribusiness. 15(1), 53-70.

Sinclair, D., 1997. Self-Regulation versus Command and Control? Beyond False Dichotomies. Law \& Policy, 19,527-559.

U.S. Food and Drug Administration. 2007. Food Protection Plan. http://www.fda.gov/food/foodsafety/foodsafetyprograms/foodprotectionplan2007/default.htm Yapp, C., Fairman, R., 2006. Factors Affecting Food Safety Compliance Within Small and Medium-Sized Enterprises: Implications For Regulatory And Enforcement Strategies. Food Control. 17(1), 42-51. 
Figure 1: A Framework for Analyzing Co-regulation in Enforcement Regimes (adapted by the authors from May and Burby (1998)).

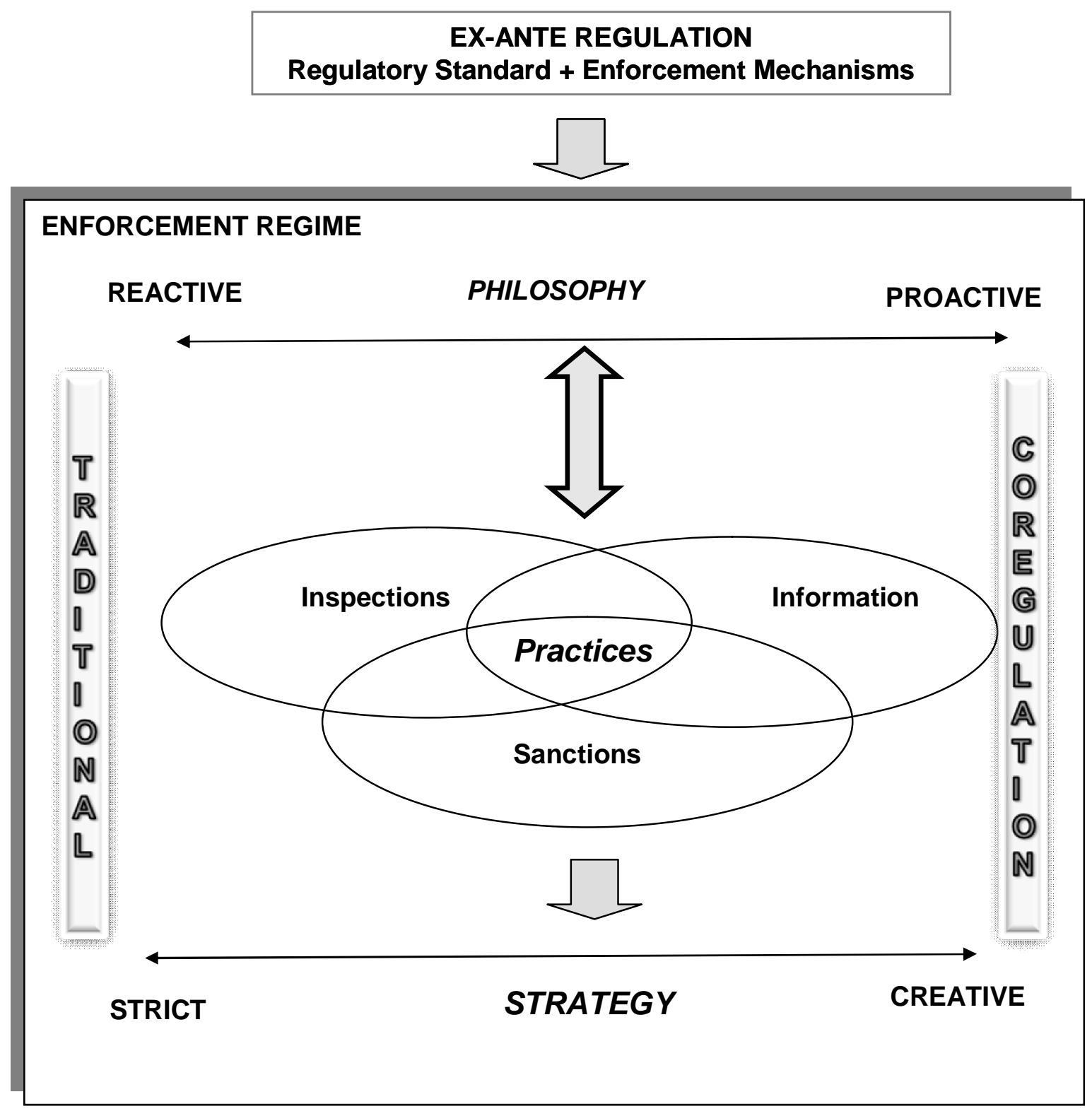


Figure 2. Distribution of ParticipantsôSafety Effort by Size of Firm under the Coregulation Program

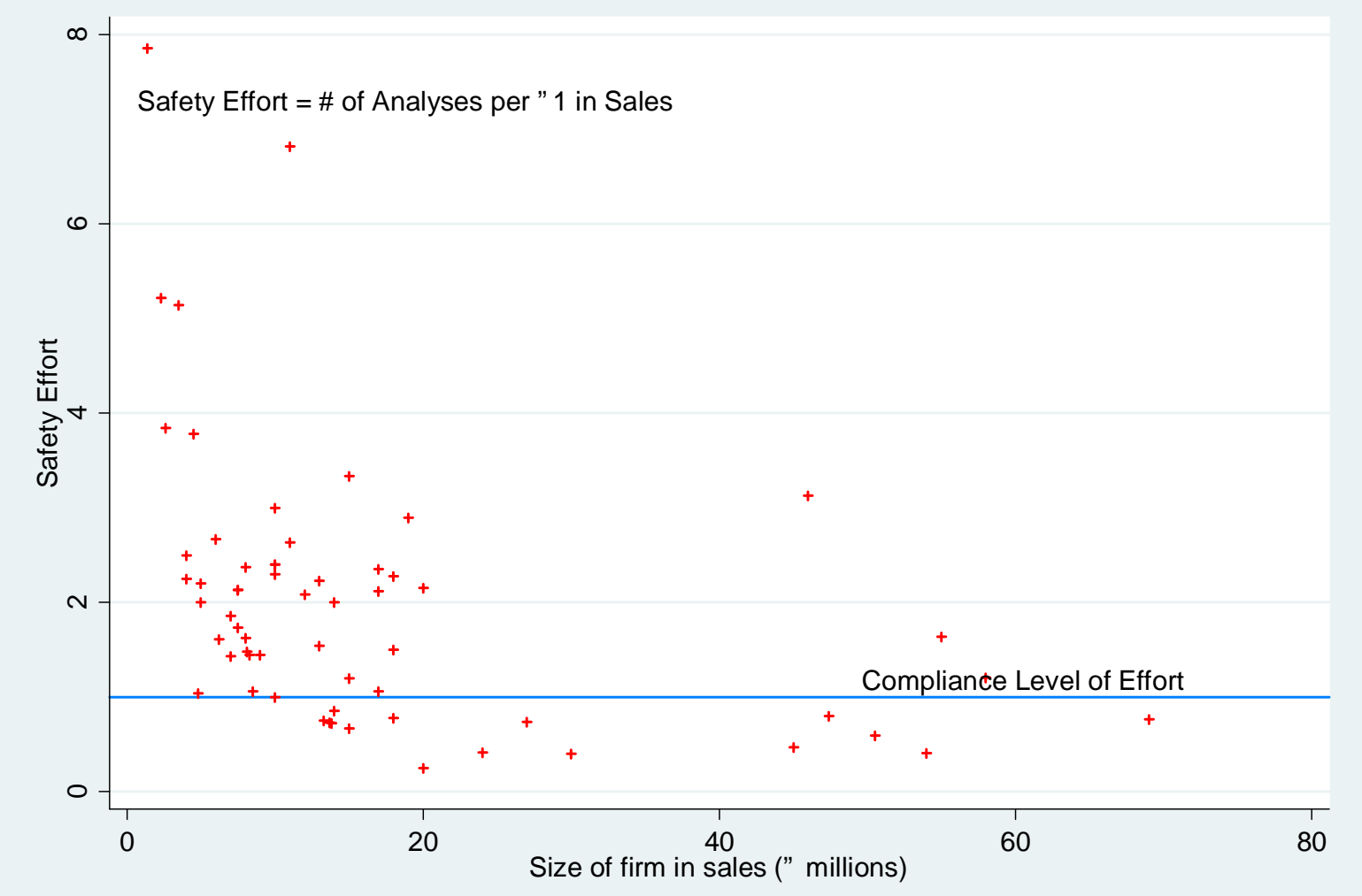


Table 1. Participation of Produce Importing Firms Surveyed in the Perpignan, France Market in Co-Regulation Program, 2006

\begin{tabular}{|l|c|c|c|c|}
\cline { 2 - 5 } \multicolumn{1}{c|}{} & \multicolumn{2}{c|}{ All Firms } & \multicolumn{2}{c|}{ Surveyed Firms } \\
\cline { 2 - 5 } \multicolumn{1}{c|}{} & $\#$ & $\%$ & $\#$ & $\%$ of Group \\
\hline Participating Importers & 66 & $67.4 \%$ & 66 & $100.0 \%$ \\
\hline Non Participating Importers & 32 & $32.6 \%$ & 12 & $37.5 \%$ \\
\hline Total & 98 & $100 \%$ & 78 & $79.6 \%$ \\
\hline
\end{tabular}


Table 2. Orientation of ImportersôSampling Plans for Co-Regulation Participants

\begin{tabular}{|l|c|c|}
\hline Orientation of Sampling Program & \# of Firms & \% of Firms \\
\hline Risky Products & 12 & $19.4 \%$ \\
\hline Products with Highest Volume & 36 & $58.1 \%$ \\
\hline All Products & 14 & $22.5 \%$ \\
\hline Total & 62 & $100.0 \%$ \\
\hline
\end{tabular}


Table 3. Number of Safety Failures Reported by Participating Firms, 2005

\begin{tabular}{|c|c|c|}
\hline \# of Failures & \# of Firms & \% of Firms \\
\hline 0 & 17 & $27.4 \%$ \\
\hline 1 & 23 & $37.1 \%$ \\
\hline 2 & 11 & $17.7 \%$ \\
\hline 3 & 7 & $11.3 \%$ \\
\hline 4 & 1 & $1.6 \%$ \\
\hline 7 & 2 & $3.2 \%$ \\
\hline 8 & 1 & $1.6 \%$ \\
\hline Total & 62 & $100 \%$ \\
\hline
\end{tabular}

